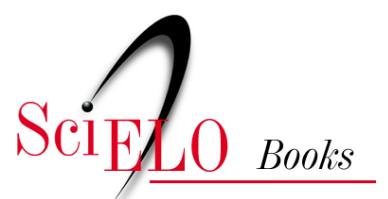

\title{
Terceiro Episódio 'Eu sou eu e minha circunstância'
}

\author{
Ana Cristina Bohrer Gilbert
}

GILBERT, A.C.B. Terceiro Episódio: 'Eu sou eu e minha circunstância'. In: Vértice do impensável: um estudo de narrativas em síndrome de Down [online]. Rio de Janeiro: Editora FIOCRUZ, 2012, pp. 115150. Criança, mulher e saúde collection. ISBN: 978-85-7541-572-6.

https://doi.org/10.7476/9788575415726.0007.

All the contents of this work, except where otherwise noted, is licensed under a Creative Commons Attribution 4.0 International license.

Todo o conteúdo deste trabalho, exceto quando houver ressalva, é publicado sob a licença Creative Commons Atribição 4.0.

Todo el contenido de esta obra, excepto donde se indique lo contrario, está bajo licencia de la licencia Creative Commons Reconocimento 4.0. 


\section{TERCEIRO EPISÓdio: 'EU SOU EU E MINHA CIRCUNSTÂNCIA' '}

Na era genômica, o corpo, considerado como um sistema, um conjunto de órgãos, tecidos, fluxos, funções, tornado foco do olhar clínico a partir do século XIX, ainda é apresentado e pensado como 'visível'. Entretanto, passa a coexistir com o corpo biomédico contemporâneo, do qual difere em escala: para além de uma interiorização do olhar do tecido para a molécula com base em instrumentos mais precisos, o que ocorre é uma reorganização desse olhar. Não se trata apenas de visualizar, mas de isolar os elementos, manipular, amplificar e reproduzir, num processo de abertura sem precedentes desse corpo à tecnologia, que requer novas formas de entendimento, regulação, padronização e ética.

É essa abertura que torna possível não apenas pensar em modificar condições de doença ou de incremento à saúde por meio de elementos externos, como dietas ou exercícios, mas trabalhar com a plasticidade humana, reconfigurando os próprios processos biológicos vitais inseridos numa 'normalidade', com o intuito de aprimorar sua dinâmica e seus resultados (Rose, 2007).

A redefinição das fronteiras entre o saudável e o doente, com o surgimento de uma terceira possibilidade, o indivíduo sob risco genético, ressalta a suscetibilidade como um importante elemento. Riscos potenciais futuros são trazidos para o presente, gerando com isso a necessidade de intervenção (Novas \& Rose, 2000). 
Os indivíduos nos quais se intervêm são encarados como consumidores livres e capazes de escoelha porque mais informados, segundo uma lógica de mercado condizente com as democracias liberais avançadas (Miller \& Rose, 2008b). É enfatizada a necessidade de um letramento genético por parte da população, que permita o entendimento das condições individuaisfamiliares e das narrativas possíveis que são vislumbradas para cada grupo específico. Assim, a capacidade da Internet de difundir informação, ainda que certos conteúdos sejam questionáveis quanto a sua qualidade e acurácia (Castiel \& Vasconcellos-Silva, 2006), torna-se um elemento fundamental, deslocando eixos hierárquicos e apresentando alternativas no processo de produção de verdades.

A condição de pessoa está cada vez mais relacionada ao discurso genético, o qual inclui imagens que são difundidas e assimiladas globalmente através de trocas simbólicas, realizadas fora dos limites das referências espaciais, por meio de material escrito, comunicação oral ou outras formas de manifestação humana. De certo modo, essas imagens transformam-se em mercadorias, cuja ampla circulação marca uma homogeneização da população em termos do seu consumo (Franklin, Lury \& Stacey, 2000).

Observa-se a crescente presença da genética no cotidiano das pessoas, trazendo à tona aspectos relacionados a parentesco, risco e identidade genéticos. Doenças herdadas geneticamente, programas de rastreamento genético, células-tronco, terapia gênica, correlações entre genes específicos e comportamentos estão presentes em revistas leigas, programas de televisão, manchetes de jornais e redes virtuais como a Internet.

A difusão cada vez maior de argumentos genéticos sobre aspectos de saúde, doença, hábitos e comportamentos modifica o olhar sobre os corpos - o corpo anatomopatológico, o corpo transparente revelado pelas tecnologias de imagem (Van Dijck, 2005), o corpo genômico -, possibilitando novos pontos de vista a partir dos quais se constroem discursos sobre o mundo, não apenas no campo da biologia. Para além das células, cuja permeabilidade aponta para a possibilidade sempre presente do risco, estão os genes com suas complexas interações, envolvendo mais incertezas 
do que certezas acerca das informações sobre cada pessoa e por isso também sinalizando riscos nas biografias corporificadas.

O processo de desnaturalização de elementos extraídos do contexto biológico, tais como o gene, e a renaturalização deles em outros contextos contribuem para a criação de novos mitos no sentido barthesiano. A ênfase dada à visualização desses elementos cria a ilusão de uma realidade cada vez mais 'real' e, portanto, mais 'verdadeira', mas que transforma o real em imagem e a imagem em real (Joyce, 2005).

Neste terceiro episódio, discute-se como o tema SD (nos aspectos de conhecimento especializado, valores, crenças e opiniões) é tratado e veiculado nas narrativas verbais e não verbais que compõem as reportagens da revista Veja e do jornal O Globo. Os significados nelas presentes revelam como esses aspectos vêm sendo assimilados, transformados e difundidos socialmente, assim como sua contribuição para demarcar os limites de identidade de pessoas com SD e forjar escolhas a ela relacionadas.

A terceira entrada de voz desenvolve o tema variando o tom e o ritmo, espelhando-o, modulando-o, resumindo-o ou mesmo expandindo-o; de certa forma, reúne fragmentos do tema espalhados pela música.

\section{AprimORAR O NORMAL: A PLASTICIDADE DOS CORPOS}

Novas formas de entendimento da corporalidade são consideradas nas relações que os indivíduos estabelecem consigo mesmos, no seu reconhecimento como sujeitos, e também com as autoridades biomédicas, sejam elas especialistas no que se pode considerar como existência somática, sejam em novas formas de atividade pastoral, com funções de aconselhamento, cuidado e suporte. Tais atividades não pretendem direcionar as pessoas em suas escolhas, porque se supõem calcadas em autonomia de decisão, sobretudo nas sociedades neoliberais.

O olhar clínico, como ferramenta diagnóstica, deixou de ser monopólio médico e passou a ser regulado também por circunstâncias externas, tais como os procedimentos estandardizados da medicina baseada em evidências, 
ou interesses econômicos relacionados a seguros-saúde ou à indústria farmacêutica.

O público em geral está cada vez mais atento a formas de aperfeiçoar o corpo tangível, visível, a um só tempo fragmentado e unificado que age e se comporta por meio de diferentes tecnologias relacionadas a cura de doenças, dietética, exercícios, cosmética e intervenções invasivas, como a cirurgia, a fim de melhorar o seu funcionamento (como, por exemplo, as numerosas próteses, hoje corriqueiras) ou a sua aparência (cirurgias reconstrutoras ou cosméticas). E para tanto, busca informação em manuais de boa forma, reportagens em revistas, suplementos em jornais, programas de televisão, inclusive em tabloides sobre celebridades, em que novas receitas de cuidados ou novas formas de escrutar o corpo são delineadas, comentadas e estimuladas.

Apesar de a identidade de um indivíduo ser constituída de forma plural, dependente das práticas em que se insere, e a identidade genética ser apenas um dos seus aspectos em constante interação com outros elementos, tais como nacionalidade, cultura, sexualidade e religião, entre outros, fala-se cada vez mais de quem se é com base em uma existência somática alicerçada no discurso biomédico e, mais especificamente, genômico. A atuação no corpo justifica-se como melhoria física e também psicológica. É por meio dessa existência corpórea que se adquirem experiências de vida, que se estabelecem novos jogos de verdade, na acepção foucaultiana (Foucault, 2006), nas relações das pessoas com elas mesmas, e que se busca melhorar a si mesmo. Emoções, sentimentos, desejos, humores tornam-se acessíveis graças aos fenômenos moleculares alvos de visualização.

Além das artes performáticas e visuais que expuseram o corpo em suas várias dimensões por meio de diferentes leituras, ele passou a ser exibido na mídia, em programas televisivos, por exemplo, em que a intervenção e a manipulação por tecnologias biomédicas são o foco, evidenciando o apelo e a fascinação que o corpo, com suas representações, significados e funcionamento, exerce sobre o público. Nesse sentido, Hacking $(2005,2007)$ sugere que o corpo, longe de ser naturalmente dado, está 
sendo reafirmado como aquele concebido por Descartes, um corpo mecânico, diferente da mente, com partes intercambiáveis e passível de ser modificado; um corpo com o qual cada um se relaciona como sendo um 'outro'. A desestabilização que o desenho genômico traz aos corpos em sua definição como natural e estável provoca mudanças também nas instituições que se apoiam nesse conceito de corpo. Novas formas de construção do 'eu' são solicitadas, com novas práticas e novos caminhos de expressão corporal.

O processo de visualização dos corpos provocado pelo surgimento de tecnologias de imageamento, tais como os raios X em 1895 e, posteriormente, a tomografia computadorizada (TC), a ressonância magnética (MRI) e a tomografia por emissão de pósitrons (PET), que expuseram os corpos em privacidade e profundidade, traduziu-se metaforicamente como uma forma de autoconhecimento (Joyce, 2005). Hoje, a possibilidade cada vez maior de acesso aos corpos aponta para um movimento que deixa de ser predominantemente vertical, expandindo-se horizontalmente - isto é, o gene que antes aparecia em discurso como algo relacionado à determinação e espacialmente escondido em profundidade, verdade a ser revelada, hoje é considerado pelo discurso genômico como sendo da ordem de superfícies, conexões, probabilidades e novas formas de conhecimento de si. O foco é deslocado do gene para os seus processos de regulação, expressão e transcrição e, em última instância, para os processos celulares dos quais participa e a relação entre seus produtos (Rose, 2007).

O corpo tangível convive com o corpo molecular que é objeto da biomedicina contemporânea, cujo olhar oferece novas formas de visualização da 'vida em si' e do aparato tecnológico que as torna possíveis, e que diz respeito mais a complexas redes não hierarquizadas e suas conexões (Franklin, 2000). O corpo fragmentado pelo olhar anatomopatológico e pelas tecnologias de visualização ganha nova leitura diante do olhar molecular, sendo reformulado fora da moldura imposta pela polaridade fragmentação-unificação.

O corpo molecular ganhou espaço na mídia e foi incorporado ao cotidiano das pessoas: células-tronco, seleção de embriões, animais 
transgênicos, novas tecnologias diagnósticas são alguns dos tópicos encontrados em textos e imagens nas reportagens analisadas.

Da mesma forma, cada vez mais aspectos da vida são expressos e publicamente discutidos em termos de probabilidades e estratégias de controle. Cabe aos profissionais responsáveis por atividades pastorais a mediação entre os pacientes e as informações expressas por meio de cálculos probabilísticos, 'futuro-orientadas', preditivas e baseadas em evidências, indicando suscetibilidade para doenças futuras, ainda quando são incapazes de sinalizar mais do que promessas, especialmente com relação a traços comportamentais.

Entretanto, a presença crescente desses temas na mídia não significa que o assunto seja sempre tratado com profundidade ou mesmo propriedade. Em muitas situações, ele é referido simples e uniformemente como 'a genética', ou ainda em substituição ao que é considerado como 'natureza' ou 'natural', isto é, aquilo que é dado a cada um ao nascer. Em outras, a mensagem veiculada reafirma o papel da ciência em reconfigurar o que seria da esfera do biológico, na medida em que expande os limites tidos como naturais, conformando, portanto, uma segunda natureza, com inúmeras alusões a fantasias sobre a manipulação do humano. Em ambos os casos, a sugestão implícita deixada em aberto é a definição do ser humano como indivíduo somático e, como tal, a possibilidade de sua manipulação tecnológica pelo próprio homem, resultando em destinos genéticos que são naturalizados.

Nas reportagens, os argumentos relacionados à possibilidade de se forjarem os corpos tendem a uma possível aplicação direta aos seres humanos dos últimos achados experimentais, simplificando o que é complexo em suas múltiplas interações e, muitas vezes, enfatizando resultados específicos em detrimento de outros aspectos importantes como os metodológicos (Castiel, 1999; Brechman, Lee \& Cappella, 2009). A passagem do âmbito daquilo que é substância corporal para o âmbito das noções abstratas, veiculadas pelas pesquisas ou por informações probabilísticas sobre riscos, dá-se pela capacidade do gene de aludir a domínios diversos, o mundo experiencial, o ficcional e o especulativo. 
A vida, tratada no nível molecular, deixa de estar limitada pelos extremos de normatividade e passa a lidar com o aspecto da suscetibilidade e da reconfiguração no presente dos processos vitais relacionados a uma eventual doença futura cuja incerteza descortina uma ampla gama de possibilidades apenas vislumbradas. Nas narrativas analisadas, as especulações no presente encontram respaldo nas referências feitas a um futuro não muito distante em que as descobertas serão possíveis. As frases assim construídas enfraquecem o peso da incerteza e transformam especulações em 'fatos', cuja aparência de 'solidez' contribui para a obliteração de elementos controversos ou passíveis de contestação (Fennell, 2009).

A modificação daquilo que é da esfera do biológico está presente na pauta do material editado para o público em geral, não mais como apelo médico, apesar de calcado em bases científicas, mas como produto a ser escolhido, adaptado a cada indivíduo e consumido além do nível orgânico.

Os indivíduos são instados a decidir em aspectos ligados à saúde e à relação com seus corpos; entretanto, alguns autores argumentam que a noção de escolha autônoma baseada exclusivamente em informações objetivas configura-se mais como retórica do que como realidade, mas ainda assim faz parte do ideário genético contemporâneo (Felt et al., 2009; Kerr, 2004). As relações são dinâmicas, e os limites entre direcionamento, coerção e consentimento são tênues, especialmente quando envolvem a responsabilidade (obrigação?) por comunicar o risco a outros membros da família potencialmente afetados.

No título deste episódio, faz-se uma referência à conhecida frase do filósofo espanhol José Ortega y Gasset (2007). Para o autor, 'circunstância' é tudo aquilo que rodeia o homem, a realidade em seu imediatismo sem julgamentos, ao mesmo tempo externa e interna. ${ }^{2}$ Para que possa dispor de sua capacidade ao máximo, é necessário que o homem tome consciência de sua(s) circunstância(s).

A frase de Ortega y Gasset (2007) é aqui revisitada como uma analogia. Se para o autor a 'circunstância' é indissociável do indivíduo em sua forma de se orientar no mundo, aqui ela é acrescida da dimensão genômica, da mesma forma interna mas entrelaçada à realidade exterior, familiar, 
cultural. Tal releitura está relacionada à presença cada vez maior dessa dimensão na esfera pessoal e na percepção do 'eu' como indivíduo somático, cuja convivência com cálculos sobre risco torna-se rotineira, produzindo um profundo rearranjo das relações da pessoa consigo mesma e com o mundo.

Ao falar de genes, o indivíduo utiliza uma referência que é inegavelmente somática, mesmo quando desfocada por cálculos probabilísticos; ao mesmo tempo, refere-se a algo que é como uma força motriz dessas características corpóreas, determinante de um futuro, ou um "ator interior", nas palavras de Barbara Duden e Silja Samerski (2007: 172), mas que, apesar de interno, revela-se destacado daquele que fala. E acima de tudo, incorpora essa dimensão à sua visão de mundo, às suas expectativas de realização e de futuro. Herança transmitida que alude a um passado familiar e a um presente somático, os 'genes' (ou a dimensão genômica) compõem a 'circunstância' e, como em Ortega y Gasset (2007), são um dos elementos definidores da identidade individual e com o qual cada um deve aprender a se relacionar, no sentido de assumir responsabilidades e fazer escolhas no presente tendo em vista um (projeto) futuro.

\section{As Reportagens}

Além do texto, a imagem presente numa reportagem é em si uma mensagem autônoma formada por três elementos: uma fonte de emissão, que abarca os responsáveis por fazê-la, escolhê-la entre outras imagens, editá-la e comentá-la (título, legenda); uma fonte de recepção, que é o leitor; e um canal de transmissão, que é o próprio meio (jornal ou revista); ou melhor dizendo, essa imagem é composta por todas as mensagens que a acompanham (texto, título, diagramação e até mesmo o nome do meio de comunicação, uma vez que este orienta a leitura da mensagem). Imagem e texto estão em relação constante, apesar de serem diferentes entre si (Barthes, 1977).

É certo que a imagem fotográfica não é a realidade, mas apresentase como seu análogo perfeito, sendo essa sua característica primordial que a leva a ser entendida como mensagem sem nenhum código. Contudo, de acordo com Barthes (1977), entende-se que esse tipo de imagem, conside- 
rada imitativa, contém na realidade dois tipos de mensagem: uma denotativa (aquilo que a faz análoga à realidade) e outra conotativa (que expressa valores da sociedade sobre tal aspecto da realidade).

Tende-se a considerar que as imagens e os esquemas acompanham os textos com o intuito de facilitar o seu entendimento e, principalmente, a sua visualização. Entretanto, nas reportagens, em especial as que se pretendem mais especializadas, são os textos (título, corpo do artigo e legendas) que acompanham as imagens para conotá-las ou refiná-las, e o que ocorre não é mais uma redução (do texto para a imagem), mas uma amplificação, na qual as imagens são consideradas como fundamentalmente denotativas porque naturalizadas. As legendas tendem a ser incorporadas na denotação da imagem em razão de sua proximidade espacial. Em contrapartida, o título (ou manchete) e o corpo do texto têm um efeito mais conotativo, o primeiro por ser enfático e provocar uma quebra; o segundo, pela distância que mantém em relação à imagem. Em muitos casos, o texto amplifica as conotações já presentes na imagem, ou projeta significados, dando a entender que tais significados surgiram na imagem (Barthes, 1977). ${ }^{3}$ Quanto mais tecnocientífico/literal se propõe o texto, mais os significados construídos aparecem mascarados, tanto no texto quanto na imagem, na forma de um significado tido como 'natural', como forma de legitimação de verdade.

Na revista, as reportagens são compostas por um título (manchete) claramente figurativo e imbuído de juízo de valor, que tem como função o apelo à leitura, e por um subtítulo que pretende ser mais 'científico' (literal) e transmitir objetividade, neutralidade e seriedade. ${ }^{4}$ Em algumas pequenas notas, traduções de pesquisas recentes, um único título 'científico' as introduz. No jornal, título e subtítulo (quando presente) tendem a ser menos valorativos, apesar de manterem a relação citada, o primeiro mais figurativo que o segundo, e a intenção de transmitir um conteúdo literal prevalece (apesar da presença de metáforas convencionais), principalmente quando a reportagem está relacionada aos avanços na área da genômica. ${ }^{5}$ Tais arranjos cumprem o papel de definir a moldura dos códigos sociais dentro da qual o texto deve ser compreendido. 
A forma como o discurso é construído tem como uma das funções manter uma estabilidade que se vê questionada pela novidade das notícias. Essa estabilidade manifesta-se no uso recorrente do tom de acordo com o tipo de mídia impressa, como jornais 'de primeira linha' como O Globo, revistas como Veja ou tabloides (Bignell, 2002), por exemplo. A escolha das imagens refere-se não apenas ao texto ao qual elas vêm associadas, mas à seção do jornal ou revista escolhida para veicular a notícia, o que no caso das fontes desta investigação varia significativamente.

A metáfora do teatro proposta por Van Dijck (1998), na qual a circularidade predomina sobre um modelo linear de difusão do conhecimento científico, é importante em se tratando de jornalismo científico que faz a mediação entre o círculo especializado e o público em geral.

Para que possam transitar em diferentes âmbitos, as palavras que designam conceitos científicos necessitam de certa flexibilidade para serem compreendidas, o que resulta no uso de significados diferentes, muitas vezes imprecisos, dependendo da situação em que são empregadas. Os fenômenos se modificam, requerendo novos conceitos, novas formas de pensar e novo vocabulário para melhor expressá-los; porém, o conjunto de palavras que os designam nem sempre acompanha as mudanças, como é o caso do gene, e adquire na imaginação do público uma cristalizada qualidade mítica que pode levar a assunções errôneas.

As metáforas são abundantes no discurso científico, decorrentes do esforço de entender e dar sentido a certos fenômenos, originando outras mais, relacionadas entre si. Uma metáfora envolve dois elementos: o tópico, que é o sujeito literal ou primário, e que é expresso de forma figurativa pelo sujeito secundário, o veículo. O pensamento metafórico se estabelece por meio de uma comparação entre dois fenômenos (ou termos) a princípio não relacionados entre si, que passam a compartilhar atributos, tornando-se semelhantes. Quanto maior a diferença literal entre as categorias às quais o tópico e o veículo pertencem, mais metafórica será a comparação (Knudsen, 2005).

Frequentemente, metáforas científicas começam como interpretações hipotéticas e gradativamente, ao serem discutidas e analisadas, vão 
se transformando em conceitos cuja origem apenas remonta a uma metáfora. Contudo, nesse processo, parte da fluidez é perdida, e as metáforas podem vir a perder capacidade de abertura, cristalizando-se. Metáforas científicas inovadoras tendem a uma expansão conceitual; tornam-se metáforas-raiz, desdobrando-se numa rede de expressões metafóricas secundárias. Quando uma metáfora pouco usual é expressa, existe uma tendência por parte do autor a destacá-la de algum modo, levando o leitor a perceber que se trata de uma metáfora. No entanto, metáforas convencionais já foram incorporadas ao vocabulário científico, sendo desnecessário tal destaque (Knudsen, 2005).

Em artigos de jornalismo científico, certas metáforas-raiz já tornadas convencionais são transmitidas como novas, entre aspas, apoiadas por metáforas secundárias estruturantes, imbuídas de um caráter que não é mais o da novidade, mas pedagógico, visando ao letramento do público em geral (Knudsen, 2005). ${ }^{6}$ Nas imagens, metáforas visuais cumprem o papel de transformar ideias teóricas em significados concretos (Van Dijck, 2006).

Barthes (1977) destaca seis tipos de procedimentos que servem ao propósito de conotar a imagem, isto é, dotá-la de um segundo significado, e que podem ou não estar presentes. Os três primeiros se referem ao que é denotado na foto e suas conotações. São eles: os 'efeitos especiais', como introduzir uma pessoa no cenário por meio de manipulação digital, por exemplo, dando a impressão de que ela 'estava lá'; a 'pose', que se refere ao código gestual utilizado não apenas como parte da mensagem a ser transmitida, mas também estabelecendo segundo qual código cultural ela deve ser 'lida'; a 'presença de determinados objetos', traduzindo significados que se quer incorporar à imagem. Destes, apenas o primeiro não é observado nas reportagens: gestos (indicando ações), ângulos de tomada da fotografia (quase sempre encarando a lente) e objetos (como a presença de equipamentos de laboratório para falar em exame de DNA, indicando 'cientificidade', 'assepsia', 'neutralidade', ou ainda de uma estante de livros numa entrevista com um escritor) compõem os significados a serem transmitidos. 
Os três procedimentos seguintes se referem à imagem e seu contexto: 'fotogenia', em que o foco é a imagem em si, realçada por efeitos de luz, exposição e impressão; o 'uso de códigos estéticos', que em muitos casos pode 'conflitar' com as conotações de objetividade e imediatismo que se quer transmitir; e a 'sintaxe', colocação de uma imagem próxima à outra, como palavras dispostas em sequência de acordo com a sintaxe da linguagem (por exemplo, as fotos sequenciadas que produzem uma narrativa no tempo). O uso de técnicas de iluminação, obedecendo a códigos estéticos (valorizando rostos ou expressões, por exemplo), e a disposição de certas imagens como narrativas são procedimentos utilizados com menor frequência nas reportagens do jornal do que nas da revista, uma vez que esta tende a apresentar mais imagens.

Por fim, permeando todas as narrativas, está o elemento identitário do meio de comunicação em si, cujos nomes sugerem tendências e significados específicos, gerando crítica ou concordância entre seus leitores.

Os textos analisados podem ser divididos em três conjuntos de temas: 1) inclusão de pessoas com SD na sociedade; 2) atualização do conhecimento na área da genômica; e 3) o uso de (novas) tecnologias reprodutivas. São distribuídos pelas diversas seções: de Ciência e Saúde a Livros (na Veja) e de Ciência e Vida a Esportes (no Globo), chamando a atenção para o fato de que o interesse em genética e, especificamente, em SD é capaz de arrebanhar leitores com os mais variados interesses, insinuando-se como uma estratégia de tais meios de comunicação para captura de público.

\section{IMAGENS DA INCLUSÃO}

A maioria das ocorrências em ambos os meios de comunicação (em torno de $62,5 \%$ na Veja e $88 \%$ em O Globo) prioriza o tema da inclusão, com foco na diminuição do preconceito e dos entraves sociais que ele acarreta, contrastando com a situação em outros países, como Estados Unidos ou Reino Unido, nos quais a inclusão é tratada em termos primordialmente práticos. Os anos de 2006 e 2007 foram os mais prolíficos em reportagens, alavancadas pelo sucesso da novela Páginas da Vida, exibida pela 
Rede Globo de Televisão. O tema é abordado das mais variadas formas, principalmente relatos de experiências bem-sucedidas e histórias de pessoas famosas que têm um filho com a condição (como o príncipe D. João de Orleans e Bragança, o jogador de futebol Romário ou o fotógrafo Sebastião Salgado), mas também lançamento de livros, campeonatos, campanhas e outras produções culturais, tais como documentários e novelas.

Os grupos de pais que militam pela causa da SD promovem palestras, reuniões, debates, nos quais o tom confessional predomina, a fim de tornar público como é ter um filho com SD, de discutir aspectos práticos relativos aos cuidados necessários ao seu desenvolvimento e, mais importante, de transmitir mensagens positivas sobre essa experiência. Esses eventos compõem uma espécie de cenografia, um termo originado do teatro, que se refere a uma forma de "construir, adaptar, transformar e preencher um espaço dramático" (Copeman, 2009: 73), no caso, o território da SD, em que diferentes atores coreografam encontros com o intuito de cultivar um senso de unidade. Através dos meios de comunicação tais eventos são divulgados, seja com o objetivo de atrair público, seja para constatar os avanços no processo de inclusão neles manifestos e narrados.

Nos livros e blogs analisados anteriormente, a SD é implicitamente negada por meio da tentativa de eliminação de sua marca diferencial e dos limites por ela impostos. O corpo identificado pelos sinais que revelam a condição genotípica é invisibilizado pelo espírito (ou alma) sem marcas, (re)afirmando uma dicotomia. Já nas reportagens, apesar de se perceber a mesma dicotomia, a marca da SD está sempre presente, explicitada pela invariável definição das pessoas como portadores (de deficiência, da síndrome, da anomalia, do defeito genético), sugerindo uma analogia com o ato de portar um documento de identidade que é guardado ou retirado do(a) bolso(a), e que no tocante a uma condição genética não é possível. Também são referidos como 'os Down', utilizando-se uma sinédoque, caso especial de metonímia, como recurso linguístico que significa nomear um ser por uma palavra que indica apenas parte dele. Dessa forma, as conquistas são narradas dentro da moldura da identidade genética, mas num tom que se apresenta ambíguo. 
As narrativas em SD presentes nas reportagens sobre inclusão parecem evocar o conceito de grotesco da cultura popular medieval e barroca, anterior ao final do século XVIII, conforme analisado por Bakhtin (1984) no seu estudo sobre a obra de Rabelais. Nela, o grotesco e o mundano associados constituem uma alegoria das relações hierárquicas, entre algo imposto de cima e o desejo de mudança que brota nas camadas submetidas, ou entre o oficial e o marginal (a Igreja Católica, em Rabelais, e o momento político da Revolução Russa, em Bakhtin). Em sua análise, ao discutir o momento histórico de Rabelais, Bakhtin discute o seu próprio tempo.

A manifestação do grotesco e do mundano significa uma destruição simbólica, uma subversão da ordem cultural dominante e uma renovação popular, uma forma especial de vida criativa. O corpo grotesco em Rabelais, exacerbado em suas características satíricas, reforça a oposição às novas práticas repressivas no final da Renascença não apenas ao corpo, mas também à linguagem. Apresenta-se aberto, inacabado, sem totalidade corporal e identitária, aludindo à multiplicidade e não à unidade, diferente do corpo intacto, fechado e sem 'costuras', que surge como modelo de normatividade a partir do modelo clássico, e que traduz o ideal de individualidade fechada em si mesma.

A alusão ao conceito, ou ideia, de grotesco em analogia às narrativas em SD sugere um desafio à atual ordem vigente, o padrão do 'normal', que como tal considera qualquer outro modelo como inválido ou prejudicial. O corpo com SD difere do padrão harmônico e sem conflitos do corpo normal considerado belo. A presença do cromossomo extra traduz-se como desequilíbrio, e é nesse desequilíbrio que um novo equilíbrio deve ser encontrado.

A criança com SD já foi considerada como 'inacabada', conforme descrição feita por Shuttleworth em 1883 (Stratford, 1982), o que se deveria à manutenção de aspectos equivalentes ao segundo ou terceiro mês do desenvolvimento embrionário. Para Stratford, que escreve em 1982, essa incompletude ainda faria sentido, só que não tanto em termos patológicos, mas sim psicossociais. E complementa citando outro autor, Thomas Weihs, cujas palavras chamam a atenção para o fato de que, se por um 
lado essa cobertura corporal insuficiente destaca e separa a criança com $\mathrm{SD}$, por outro é o que desperta um senso de proteção e compaixão em relação a ela por parte dos demais.

A presença da $\mathrm{SD}$, como qualquer outra condição que implica uma modificação no padrão corporal considerado 'normal', traz uma quebra, uma alteração drástica no campo perceptual, principalmente em termos visuais, que deve ser racionalizada e contida e que se relaciona ao poder do olhar. É pela percepção dos sinais pela pessoa 'normal' que a pessoa com SD se torna 'outro', estranha e ameaçadora em sua 'desordem' e consequente possibilidade de 'fragmentação', reverberando o que seria, em termos lacanianos (Lacan, 2007), a imagem de um primitivo estado em que o corpo é experienciado como fragmentado. A racionalidade é um dos elementos que fazem a contenção do corpo deficiente e protegem a pessoa 'normal' da angústia que a desordem/fragmentação inspira. Na tentativa de evitar o desconforto, o corpo deficiente é reconstituído imaginariamente como forma de reparar a quebra perceptual, recuperando sua completude/ organização (Davis, 1997). A tendência é polarizar, dividindo os corpos entre capazes e incapazes, completos e incompletos, disciplinados e indisciplinados. A reafirmação constante das vitórias alcançadas pelas pessoas com SD, ou a exibição daquilo que são capazes de fazer, sugere esse efeito, livrando as pessoas 'normais' da percepção do corpo deficiente.

Os sinais da SD parecem dissociar-se da totalidade corporal; os olhos amendoados traduzem a vida humana individual e autossuficiente, mas a boca com a presença de uma língua protusa expõe e torna-se sinônimo do retardo mental. O Filho Eterno, livro de Cristovão Tezza (2007), provoca desconforto ao evidenciar o desafio que a SD impõe ao padrão de normalidade aceito socialmente, desafio este que precisa ser arduamente negado. No livro, a incompletude do filho com SD aparece na falta de ligação deste com o mundo à sua volta.

A crítica ao livro, apesar de ressaltar a beleza da narrativa, é carregada de adjetivos valorativos disfóricos em relação ao personagem que minimizam o incômodo diante do exposto pela realidade ficcional. A crueldade é considerada a principal qualidade do livro, em que a brutalidade 
das palavras é comparada ao uso do termo 'mongoloide' nos anos 80 para designar pessoas com SD, resquício da linguagem evolucionista usada por Langdon Down ao descrever a síndrome - comparando o seu fenótipo com raças consideradas 'inferiores'-, mas também da relação entre as palavras e as coisas pela similitude. Ainda segundo a crítica, o personagem considerado como alter ego do autor é, de certa forma, 'redimido' no final do livro pelo momento fugaz de harmonia familiar, traduzindo o cotidiano sem questionamentos que apazigua a vida de todos.

A importância dos olhos amendoados como elemento identitário na SD fica evidente no manifesto lançado no site da campanha "Ser diferente é normal", 7 criada pelo Instituto MetaSocial contra todo tipo de discriminação e segregação, utilizando a SD como bandeira e símbolo desse desejo de inclusão, com o intuito de "mostrar ao Brasil e ao mundo que ser diferente é normal". Para tanto, utiliza-se de uma ferramenta tecnológica que fotografa as pessoas e, por meio de manipulação digital, produz uma segunda foto 'como se' elas tivessem SD. Ao se observar atentamente a transformação, percebe-se que a mudança se dá unicamente nos olhos, elemento-chave no reconhecimento da imagem de alguém com a síndrome. Porém, essa mesma modificação já se apresenta alterada: o formato 'típi-

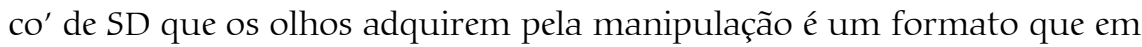
si já sofreu uma correção plástica, isto é, são olhos de alguém com SD que se submeteu a uma correção de formato para modificar o estereótipo típico da síndrome. Essa ferramenta aparece numa das ocorrências do Globo, em $2007,{ }^{8}$ quando foi veiculada na televisão com a participação de diversas atrizes, com texto que apontava para os "pequenos detalhes que fazem muita diferença" e conclamando o público a dizer não ao preconceito, começando a "ver o mundo com outros olhos".

Apesar de alardear o repúdio à discriminação e a defesa da aceitação da diferença e sua inclusão, o que essa campanha indiciariamente promove é a literalização da imagem do 'mesmo'. Dito de outra forma, para que a inclusão seja possível, é necessário que todos se apresentem com a mesma face, a face da SD tornada 'normal', eliminando diferenças e tornando-se 'mesmo'. 
Ao se analisarem as edições entre 2000 e 2009 , podem-se acompanhar as sutis modificações no vocabulário usado para se referir às pessoas com SD ou apenas à $\mathrm{SD}$, as quais seguiram o compasso do mapeamento do genoma humano e dos resultados das pesquisas na área da genômica e das tecnologias reprodutivas.

Uma importante modificação no discurso, que aparece em setembro de $2006,{ }^{9}$ diz respeito à denominação da SD não mais como doença, mas como acidente genético. A renomeação ocorre no nível do discurso não especializado, uma vez que a SD continua a ser definida na Classificação Internacional de Doenças (CID) no capítulo de "Malformações congênitas, deformidades e anomalias cromossômicas". Contudo, esse é um dos elementos importantes do movimento de inclusão que surge no final da década de 1990 e que ganha força no início do novo milênio, aliado ao rechaço à ideia de prevenção por meio da interrupção do nascimento de crianças com SD diagnosticadas intraútero.

O discurso da inclusão nas narrativas analisadas apresenta-se ambíguo ao tentar conciliar a imagem múltipla da pessoa com SD, com capacidades e limitações, à da imagem unificada da normalidade, mas que é apresentada atrelada a um excesso de adjetivos que mais reforçam a segregação do que incluem. Ao veicularem alguma conquista alcançada por essas pessoas, a presença de advérbios tem o papel de frisar a deficiência, acrescentando uma circunstância que modifica o sucesso narrado. Por exemplo, após falar sobre as várias atividades de um rapaz com SD que toca flauta doce, é dito sobre ele: "Obviamente, como portador de deficiência mental, (...) jamais chegará a ser um grande concertista. Mas não é isso o que se espera dele"; ou ainda: "os deficientes não apenas estão sendo incentivados a frequentar a escola até o colegial - sempre recebendo atenção especial dos professores, evidentemente - como também sendo preparados para o mercado de trabalho" ${ }^{10}$ Não é a constatação da limitação que chama a atenção, mas a presença da comparação com a normalidade que permanece camuflada na forma de um self ativo.

Nos sentidos e imagens sobre inclusão veiculados nas narrativas, da mesma forma que no grotesco medieval, percebe-se uma tentativa de 
desafiar a ordem vigente estabelecida pelo padrão de normalidade, por meio da exposição de como as pessoas com SD vivem, agem e participam da sociedade. Contudo, essa tentativa se enfraquece ao ser revelado o seu caráter ambíguo que, apesar de clamar por uma mudança da moldura atual, reafirma o modelo vigente, entrega-se a ele como único possível e define uma única forma de ser humano. As pessoas com SD são confinadas numa categoria homogênea globalizante (são especiais, dóceis, prestativas, únicas, iguais a qualquer criança), e sua individualização só acontece se tornadas normais, ou seja, quando as conquistas são narradas e destacadas. O que poderia ser multiplicidade de vozes prossegue como monólogo.

\section{Escolhas Circunstanciais}

Dois outros temas são privilegiados pelas reportagens: a atualização do conhecimento na área da genômica (cerca de 12,5\% na Veja e 7\% em O Globo) e o uso de (novas) tecnologias reprodutivas, que incluem técnicas de rastreamento e diagnóstico pré-natais e de reprodução assistida (em torno de 25\% na Veja e 5\% no jornal O Globo). Em ambos, a SD aparece como o exemplo mais comum, às vezes apenas nomeada, por se tratar de uma das condições genéticas mais frequentes e com maior sobrevida e ser facilmente reconhecida pelo público em termos fenotípicos, o que contribui para tornar a notícia divulgada mais significativa para o público em geral. Os dois grupos são analisados em conjunto por envolverem aspectos comuns à sua discussão, buscando-se identificar a forma como genes, herança genética, testes de rastreamento e diagnóstico e técnicas de reprodução assistida são apresentados ao público e como são enfocados aspectos como informação, risco, escolhas e prevenção em relação à SD.

As narrativas relacionadas à atualização do conhecimento em genômica buscam promover o letramento do leitor nos avanços ocorridos na área, num processo que não apenas informa, mas tenta tornar significativo o conhecimento por meio da utilização de figuras de linguagem e elementos imagéticos que permitam criar uma interface entre algo distante e abstrato, pertencente ao âmbito esotérico, e o cotidiano das pessoas. 
As reportagens mais antigas, veiculadas entre 2000 e 2002, utilizam um tom espetacular para divulgar certos avanços e perspectivas entusiastas para recebê-los. São narrativas de progresso que não apenas testemunham os feitos considerados importantes, mas traçam percursos futuros, povoados de promessas de que as dificuldades enfrentadas num momento e área específicos serão vencidas pela ciência e trarão alívio ao sofrimento humano causado por doenças (como a inserção num indivíduo de "cópias normais de um gene defeituoso, corrigindo o seu genoma"). ${ }^{11}$ Substantivos como 'descoberta', 'revelação', 'decodificação', 'segredo', 'mapa', 'empreitada' e adjetivos como 'audaciosa', 'surpreendente', 'ambicioso', 'promissoras' ilustram os recursos figurativos utilizados para descrever algo que se apresenta como novo e que acena para inúmeras possibilidades, ainda que algumas fantasiosas, de entendimento do ser humano por meio do conhecimento de seu genoma ou dos modelos animais, ${ }^{12}$ isto é, pela comparação com o genoma de outros organismos, principalmente camundongos.

O mapeamento do cromossomo $21 \mathrm{em} 2000$ merece destaque pelo marco que estabelece em relação à $\mathrm{SD}$, como possibilidade de uma 'cartografia' da condição. Tanto a revista Veja quanto o jornal O Globo ${ }^{13}$ publicaram matérias sobre o assunto, cujo pano de fundo alude a uma competição, nos moldes neoliberais, entre os cientistas envolvidos no estudo e os que também participam do Projeto Genoma Humano.

A metáfora do código genético, introduzida em 1944 no âmbito da pesquisa em biologia molecular, com o objetivo de descrever e entender o processo de síntese de proteínas e que deu origem a uma série de outras metáforas (Knudsen, 2005), aparece como metáfora implícita, ou seja, sem a identificação clara entre o tópico e o veículo, e serve de alicerce para a apresentação do mapeamento do cromossomo 21 nas matérias de ambos os meios de comunicação.

Numa dessas matérias (Veja), o cromossomo é definido por meio do uso de um símile, isto é, uma expressão metafórica que explicitamente compara o veículo e o tópico enfatizando a similaridade: "uma espécie de novelo no qual está emaranhada uma longa cadeia de substâncias químicas chamadas genes". 
Na outra ( $O$ Globo), o recurso escolhido foi o imagético, com apresentação de esquemas com o intuito de definir elementos como DNA e genes, ao mesmo tempo narrando o processo de transmissão do material genético, com as contribuições materna e paterna, espacializando-o na célula. Outra imagem traz um diagrama do cromossomo 21 , assinalando as zonas críticas para diversos agravos e destacando a SD como a principal 'doença' associada. $\mathrm{O}$ texto principal da reportagem é um desdobramento do esquema, considerado denotativo, conotando-o.

A SD aparece associada ao estudo das proteínas, ${ }^{14}$ as quais são qualificadas como o "segredo da nova medicina", uma espécie de maestro com poder decisivo de ação para "orquestrar o funcionamento do corpo", e são definidas como "constituintes básicos de qualquer ser vivo - que interagem a todo momento". Disso resulta uma "sopa química" ou "sopa de vida", cuja "receita" se encontra no genoma, uma metáfora que remonta a um processo alquímico, trazendo implicitamente ideias de transmutação de substâncias espúrias em nobres, de criação do elixir da vida, ou 'panaceia', que traria a cura para todos os males e, em última instância, a imortalidade. Também receberam destaque jornalístico o que foi chamado de a descoberta da "molécula Down"15 e do gene "causador de Down", ${ }^{16}$ acenando para a possibilidade de intervenção no nível molecular em pessoas com a condição.

A distância que existe entre a abstração da pesquisa molecular, ainda que já aplicada a 'pessoas reais', e o leitor não parece ser totalmente transposta por ação das reportagens. Por não solicitar diretamente aos leitores escolhas circunstanciais em razão do que é divulgado, as reportagens (à exceção daquelas que emitem opiniões pessoais) sugerem uma isenção de qualquer cunho valorativo ou discriminatório ao apontarem para um padrão de normalidade desejável e intrínseco às pesquisas.

A ambivalência que caracteriza os genes no discurso não especializado, já comentada anteriormente, aparece nessas narrativas (e também nas narrativas em tecnologias reprodutivas) na qualificação de algo definido ao mesmo tempo como abstração e concretude e colocado no lugar do conceito científico de genótipo. O que é do domínio da especulação 
converte-se em predição diante da probabilidade de riscos futuros, e como predição torna-se significativa e poderosa porque as duas vertentes sobre o gene se mesclam: a abstrata especulativa, de um lado, e a material corporal, de outro. Alusões a mecanismos também estão presentes nos textos, evocando um modelo de corpo como máquina e dos genes como partes desse mecanismo, o qual pode estar 'danificado', 'defeituoso', com 'problemas' ou 'alterado'.

$\mathrm{Na}$ área da genômica, a pesquisa com células-tronco encontra-se intimamente ligada à medicina reprodutiva, especialmente a procedimentos de fertilização in vitro. As definições desse tipo de células referem-se a modelos emergentes de vida humana nos quais os elementos que compõem o indivíduo podem ser extraídos, recombinados e, mais importante, redefinidos. O destaque é a funcionalidade da célula e a possibilidade de redesenhá-la por meio de tecnologia aproveitando sua capacidade 'natu$\mathrm{ral}^{\prime}$, tornando-a objeto de biovalor em termos globais (Franklin, 2005). ${ }^{17}$

As narrativas em tecnologias reprodutivas, apesar de concernentes ao casal e suas decisões reprodutivas, referem-se à mulher, principalmente àquela com mais de 35 anos, ponto de corte que marca um risco aumentado para condições resultantes de anomalias cromossômicas, entre elas a SD. A idade paterna é relacionada a possíveis problemas numa reportagem em edição especial da Veja no ano de $2005 ;{ }^{18}$ porém, são reduzidos a condições de pouca gravidade, recaindo sobre a mulher o peso das consequências do envelhecimento dos óvulos.

Mulheres são vistas de maneira geral como as responsáveis pela manutenção e transmissão das histórias familiares e as mais envolvidas em procurar aconselhamento ou testes genéticos quando diante de uma doença genética existente ou potencial (Emslie, Hunt \& Watt, 2003). Pela ênfase dada nas reportagens, sugere-se que possam ser as mais beneficiadas pelo uso das novas tecnologias, e que estas permitiriam uma mitigação do risco envolvido em suas histórias, tornando-as implicitamente responsáveis pelo futuro genético da família.

Tecnologia biomédica é criada e desenvolvida no compasso das mudanças no conhecimento biomédico, das referências legais, dos valores 
culturais estabelecidos que podem ou não ser contestados, e é instrumentalizada por pessoas no exercício de suas identidades sociais (Rapp, 2000). A esfera das tecnologias reprodutivas traduz-se como um espaço biopolítico, no qual questões como aborto, infertilidade, doação de gametas e decisão reprodutiva são abordadas em suas múltiplas faces: tecnológica, política, legal e ética. A necessidade de escolha, suscitada pelos avanços da biomedicina, conecta-se a questões que envolvem algum tipo de julgamento diante de probabilidades e que se misturam com medo, expectativa e esperança. A possibilidade de intervenção em situações de infertilidade, além de incluí-la na categoria de doença tratável, operacionaliza o lidar com a plasticidade de características vitais humanas, potencializando-as (Rabinow \& Rose, 2006).

Entidades limítrofes como óvulo, esperma, ovo, células-tronco, que têm sua existência autônoma destacada por tais tecnologias, suscitam discussões sobre as fronteiras da vida, sobre novas formas antes impensáveis de conectá-las e organizá-las, sobre as definições de organismos vivos, seu uso e o destino de elementos que compõem a própria vitalidade humana e que saem do escopo da definição de genes (Rose, 2007). Sua presença no domínio público é inconteste e tais entidades tornaram-se sujeitos de intensa discussão biopolítica (Franklin, 2007; Culley \& Hudson, 2009; Lynch, 2009; O'Riordan \& Haran, 2009; Watts, 2009; Williams et al., 2009).

A noção de 'genes alterados' aparece em 2000 numa extensa reportagem relacionada a exames preventivos, ${ }^{19}$ o chamado check-up, e que inclui técnicas de rastreamento pré-natal, como a ultrassonografia morfológica e a translucência nucal, salientadas como importantes ferramentas indicativas de risco para alterações cromossômicas e malformações fetais. A materialidade dos genes é explicitada na definição "microscópicas sementes protéicas do núcleo das células", ao mesmo tempo que eles são definidos como agentes causadores de algo já presente, apenas à espera do momento para se manifestar, com poder de decisão sobre o "futuro biológico das pessoas". Apesar da referência a aspectos moleculares, o foco ainda é o corpo molar ressignificado: tais exames voltam-se não mais para pessoas doentes, mas para aquelas aparentemente saudáveis visando 
a encontrar o 'mal' (ou suscetibilidades) antes que ele se revele (por exemplo, obstrução nas coronárias, ou perda de massa óssea) e a melhorar o indivíduo e o seu viver.

Nessa ótica, o corpo é entendido como não confiável, passível de conter algum elemento hostil, devendo, portanto, ser vigiado e controlado. No texto e nas imagens, a apresentação de novas tecnologias reafirma a narrativa da conquista do espaço interno, com a presença dos mesmos elementos das viagens espaciais: um alto nível de tecnologia, a fragilidade humana e a salvação futura. O poder de ação na vida das pessoas mostra como a biotecnologia está entranhada no tecido social, determinando escolhas dentro e fora do âmbito da saúde, ora proporcionando mudanças que alteram o estilo de vida e previnem manifestações de doenças futuras, ora dando a oportunidade de 'salvação' em casos em que as alterações já estão internamente presentes, prestes a eclodir.

O oferecimento de testes genéticos é ainda incipiente nesse momento, e estes se apresentam como a "ponta-de-lança tecnológica dos checkups". O "exame dos genes" torna-os ameaças latentes ao revelarem as "predisposições biológicas": uma caixa de Pandora prestes a liberar males insuspeitados (ainda que a esperança esteja entre eles), ${ }^{20}$ ou ainda como uma bomba-relógio que pode ter sua explosão adiada ou ser desmontada por ações (médicas) eficazes.

Anos mais tarde, no final de 2008, a inclusão de consultas de aconselhamento genético e de exames de DNA no Sistema Único de Saúde (SUS), a partir de 2009, tornam o corpo molecular foco da discussão sobre a identificação precoce de doenças e suscetibilidades como forma de prevenção, por meio da análise de "mutações genéticas". ${ }^{21}$ A reportagem parte de um panorama que sugere um amplo acesso a tais procedimentos e vai paulatinamente reduzindo as áreas possíveis de aplicação. Prevenção aqui se relaciona ao fornecimento de informação relevante, capaz de contribuir para forjar escolhas de casais que desejam ter filhos e que têm o risco aumentado para alguma condição geneticamente determinada. Aspectos econômicos são também enfocados (custo do teste), sugerindo uma mercadoria que, se não fizer parte do sistema público de saúde, será acessada 
por poucos. Um dos exemplos utilizados nessa reportagem é a SD. Duas imagens compõem uma narrativa pela proximidade física com que são dispostas: de um lado, a imagem indiscutivelmente 'real' de uma criança com SD; do outro, a imagem de um gráfico representando o sequenciamento de DNA, na qual a presença de uma mão enluvada, de modelos representando moléculas e de uma lupa dão o caráter científico, objetivo e revelador da identidade em termos genéticos.

Ao longo desses nove anos, de 2000 a 2009, pode-se acompanhar os avanços nas técnicas de rastreamento e diagnóstico pré-natais, o que possibilita detectar alterações cada vez mais precoces, de maneira menos invasiva e com menor risco. Principalmente o refinamento da qualidade das imagens, com consequente poder de visualização, reafirma a ideia de 'janela' independentemente da percepção da mãe e permite acompanhar e, acima de tudo, intervir no desenvolvimento fetal. A imagem obtida deixa de ser representação do real para se tornar o real em si; ver significa saber.

Testes para marcadores bioquímicos, translucência nucal, ultrassonografia morfológica, doppler de ducto venoso, ecocardiografia, biópsia de vilo corial, amniocentese são alguns dos exames oferecidos no pré-natal e com os quais o público em geral vai se familiarizando. ${ }^{22}$ São incluídos na 'agenda' para a futura mãe ou casal, destacando com isso seu caráter individualizante, como atividades e tarefas pessoais a serem marcadas e cumpridas, mas também coletivo, concernentes às mulheres grávidas em geral e, no caso dos exames diagnósticos, àquelas com risco aumentado, detectado em rastreamento prévio ou por aspectos como idade ou história familiar. A incorporação crescente de vocabulário especializado justifica o seu uso não apenas como ferramentas rastreadoras ou diagnósticas para confirmar suspeitas sobre malformações, mas como produtos 'científicos' que concretizam memórias mediadas do bebê antes do parto, dentre elas a determinação do sexo, já incorporadas à leitura social dos processos de gravidez e parto. Mas o que acontece quando esses resultados revelam algo diferente do esperado? 
Subjacente às tecnologias de rastreamento e diagnósticas, um padrão de normalidade está definido em termos biomédicos, e o seu propósito é detectar variações nesse padrão o mais precocemente possível e com menor margem de erro, de forma a permitir ações relevantes. Esse padrão está presente nas reportagens, e estas sugerem que, enquanto determinados significados são criados e revelados durante ou após os testes, outros são silenciados.

Por conseguinte, as imagens veiculadas nas reportagens sobre rastreamento e diagnóstico pré-natais reproduzem o padrão e traduzem uma experiência agradável, casais numa expectativa positiva quanto ao nascimento, ou um caso grave, mas que teve um desenlace satisfatório. Os problemas são narrados apenas textualmente, sem imagens, como possibilidades remotas que podem ser, se não evitadas, contornadas por ações médicas precoces. O imaginário sobre fetos com algum tipo de anomalia não aparece nesse tipo de narrativas; o tom dado ao texto transmite cientificidade, neutralidade e objetividade, com o claro propósito de informar mas também de prescrever.

Numa das reportagens, o aconselhamento genético é visto como uma forma de "proteger a saúde da família", ${ }^{23}$ em outra, as novas tecnologias utilizadas nos exames de pré-natal são consideradas responsáveis por tornar "a gravidez mais segura", como forma de controle e previsão sobre aquilo que é do domínio da natureza. A ideia de mais segurança (ou de menos risco) refere-se aqui à "detecção de eventuais malformações" ${ }^{24}$ e não à prevenção de novos casos. Ao mesmo tempo, a expressão sugere um aplacamento da ansiedade inerente a qualquer gestação quanto à saúde do feto - o que coloca a mulher grávida no centro de discursos sobre risco - e da ansiedade que resulta da probabilidade aumentada por fatores diversos a ser confirmada pelos exames, o que irá requerer uma intensificação do monitoramento (Lupton, 1999).

As reportagens na área de reprodução assistida, que se referem quase que exclusivamente à fertilização in vitro, têm o caráter de produto ofertado (haja vista o tipo de público ao qual são direcionadas), como opções tecnológicas naturalizadas para solucionar problemas. São apresentadas 
como última, às vezes única, possibilidade para certas pessoas terem filhos, desejo esse subentendido como natural, normal e universal. Conforme apontado por Sarah Franklin (1997), a busca por soluções pode ser definida em termos narrativos como uma tentativa de se alcançar algo que não encontra fechamento (um filho) por uma quebra numa sequência progressiva de eventos (o processo reprodutivo).

A ideia subjacente é a de 'ajuda' que a biomedicina presta à natureza, ainda que seguindo os ditames desta última, transmitindo uma imagem de capacidade de recuperação, ao corrigir 'anomalias' por meio do controle tecnológico. A intervenção da tecnologia num processo considerado como 'natural' provoca rearranjos nos laços de parentesco - por exemplo, a presença de um(a) doador(a) - com a inclusão de novas formas de relação estabelecidas com a ciência e a tecnologia (Franklin, 1997, 2005; Culley \& Hudson, 2009; O'Riordan \& Haran, 2009).

Técnicas de reprodução assistida são veiculadas inadequadamente como tratamento, transmitindo a ideia de tentativa de adequação à norma, muito mais em termos sociais do que biológicos, uma vez que a reprodução assistida não cura a infertilidade, apenas a contorna. E, acima de tudo, são delineadas como tecnologias de esperança (hope technologies), para usar as palavras de Franklin (1997), reafirmando valores tradicionais de família por meio da esperança no progresso tecnocientífico e, em última instância, da esperança de ter um filho.

Os procedimentos de reprodução assistida, apesar do caráter de novidade transmitido no texto, são trazidos ao público como práticas já estabelecidas em centros privados de reprodução humana no Brasil, e os casos bem-sucedidos são citados para validá-los, sobrando pouco espaço para os aspectos exaustivos e dolorosos do processo. Entretanto, sabe-se que apesar da grande repercussão que tais procedimentos geraram, como narrativas de progresso rumo à conquista do desconhecido, seus limites ainda são grandes, os insucessos frequentes, e o nível de incerteza produzido é significativo (Franklin, 1997; Rabinow \& Rose, 2006). As histórias individualizadas apresentadas como exemplo nas reportagens fazem sentido porque, ao serem lidas em retrospecto, marcam o fechamento de uma 
vivência satisfatória. No entanto, os insucessos, se narrados, deixariam a narrativa em aberto, sem um sentido de finalização, o que a tornaria ambígua e impediria que o leitor com ela se identificasse.

A temporalidade linear sequencial do processo reprodutivo está presente nos esquemas que representam o passo a passo simplificado do processo, como numa receita, com o objetivo de informar o leitor. Desenhos representando um homem e uma mulher mantêm a conexão com a dimensão humana palpável, impedindo que elementos como óvulos, espermatozoides, citoplasma e cromossomos ganhem completa autonomia e se destaquem do todo que é a pessoa real. A referência ao que é considerado como "avaliação genética do embrião" em busca de qualquer "anomalia genética" 25 é explicitada em termos citogenéticos: alterações na estrutura dos cromossomos e erros no pareamento durante a divisão celular. A identidade familiar é representada mais pelo fenótipo do que o genótipo, e de forma similar ao gene, o cromossomo condensa as características corporais apresentadas pela pessoa ao mesmo tempo que representa aquilo que as determina.

Nas narrativas em reprodução assistida, a implantação de embriões, permitindo selecionar aqueles saudáveis, surge como prevenção possível, sem, contudo, ser nomeada explicitamente como tal, e a discussão subliminar diz respeito à eliminação de embriões 'defeituosos' em favor do nascimento de crianças sadias. Em ambos os meios de comunicação, o discurso torna-se escorregadio, carregado de subtextos, que são lidos de acordo com o enquadramento (no sentido fotográfico) feito pelos diferentes leitores. A discussão suscitada pelo pronunciamento de especialistas, entrelaçando os círculos esotérico e exotérico, gira em torno dos aspectos médicos, éticos e legais da manipulação de material genético e do diagnóstico pré-implantação, com consequente seleção de embriões, deixando um rastro de ambiguidade e incerteza características dos tempos considerados pós-genômicos.

Conforme apontam Sarah Franklin e Celia Roberts (2006), o processo de fertilização in vitro difere do diagnóstico pré-implantação na medida em que este último envolve uma dimensão genética, enquanto o primeiro 
atua nos níveis hormonais do organismo feminino, isto é, no corpo molar. Apesar de o diagnóstico pré-implantação usar a plataforma da fertilização in vitro e dela depender, constitui-se como uma assistência à hereditariedade e não à concepção, uma vez que tem entre seus objetivos evitar a transmissão de determinadas condições genéticas. Dessa forma, a naturalização da fertilização in vitro se agencia mais facilmente como auxílio à natureza do que a do diagnóstico pré-implantação, na medida em que este intervém impedindo o curso 'natural' do processo reprodutivo e da hereditariedade.

A ligação com o passado, o parentesco e o processo mecânico linear deixa pouco espaço para probabilidades e outros fatores intervenientes. A noção de latência, associada à de probabilidade de aparecimento, configura o discurso do aconselhamento genético. Por sua capacidade de apontar, em termos corpóreos, para aquele que fala, o gene promove uma junção entre fenótipo e genótipo. É a corporalidade dos genes que faz a ligação entre a pessoa e os conceitos estatísticos probabilísticos (distribuição estatística) para torná-los significativos, pela mediação do profissional responsável pelo aconselhamento - no caso do Brasil, o geneticista -, permitindo escolhas circunstanciais com base nessa nova informação sobre si. Torna-se necessário que o indivíduo foco do aconselhamento seja capaz de se ver simultaneamente como o 'eu' com o qual costumava identificar-se e também por meio do seu perfil de risco, construído com base em informações estatísticas incorporadas à sua história individual e familiar. Existem diferenças entre o risco comunicado pelo profissional de saúde e aquele percebido pelo paciente. Nesse sentido, o que o paciente entende como risco é mais amplo e abarca não apenas a probabilidade, mas o valor que a pessoa atribui aos desfechos possíveis, moldado segundo pensamentos e crenças que atuam como filtros no processo de tomada de decisão.

Em sentido amplo, risco pode ser definido como uma forma de ordenar a realidade, de representar eventos a fim de torná-los governáveis por meio de técnicas específicas e voltado para determinados fins (Dean, 1999). Seu caráter probabilístico impede que as previsões de adoecimento sejam lidas como inexoráveis, gerando incerteza e ansiedade diante da multiplicidade de aspectos a serem considerados (Castiel, 1999). Na biopolítica 
exercida nas sociedades ocidentais contemporâneas, a noção de risco está associada a estratégias epidemiológicas de redução de risco em termos populacionais, à administração de grupos considerados de alto risco e à identificação de indivíduos em risco, envolvendo intervenções preventivas e modificando a forma como eles são governados por outros e por si mesmos. A centralidade que o discurso sobre risco, insegurança e precaução adquire parece indicar uma nova forma de problematização que desafia o modelo de 'governamentalidade' liberal avançada (Miller \& Rose, 2008a; Dillon \& Lobo-Guerrero, 2009; Lentzos \& Rose, 2009).

O estabelecimento e a percepção de risco, ainda que ofereçam ferramentas para decisão, não podem de forma alguma antecipar a extensão das consequências de tais decisões. Em alguns casos, um excesso de informação convive com a dificuldade em articulá-la e significá-la satisfatoriamente. Testes levam a outros testes, que carregam em si seus próprios riscos de discordâncias. Nesse panorama, o direito a não querer saber pode soar absurdo, estimulando sentimentos individuais de culpa (Castiel \& Álvarez-Dardet, 2007).

A forma como as reportagens apresentam as diferentes técnicas como estratégias para lidar com e minorar a existência de riscos concernentes à população em geral, em termos epidemiológicos, ou a determinados indivíduos, em particular, reforça a posição de que o gerenciamento do risco, feito por meio da escolha por tal ou qual técnica, pertence à esfera individual privada. Por conseguinte, novas relações se estabelecem, interligando conhecimento especializado e diferentes formas de estar no mundo, através de inúmeras mediações, como de profissionais de saúde e dos meios de comunicação, por exemplo. A introdução do eixo genético no entendimento de doenças expande a sua compreensão, tornando-as assunto familiar e não apenas pessoal.

Em se tratando de SD, o elemento de risco associado nas narrativas, que é apresentado quantitativa e qualitativamente, é a idade materna avançada e o envelhecimento dos óvulos, podendo levar a erros na divisão celular que causariam a trissomia do cromossomo 21. No entanto, o caráter 'natural' com o qual esse fenômeno é revestido esvazia a noção de prevenção via 
"consciência do risco" (Castiel, 1999: 63), ainda que seja claro que nem sempre o acesso à informação é suficiente para gerar estratégias preventivas (Castiel, 1996, 1999). Por sua vez, a ação dos grupos de pais militando a favor da inclusão e contra a discriminação desses indivíduos, e testemunhando sobre as melhorias significativas alcançadas em aspectos como estimulação precoce, acompanhamento clínico, educação e participação na comunidade, parece ter um papel fundamental. Subliminarmente, as imagens e os significados associados à SD, difundidos e reafirmados socialmente, somam-se como fatores preponderantes que determinam a escolha por realizar ou não testes pré-natais para determinar a presença da SD no feto ou, de forma mais definitiva, a interrupção da gestação.

O principal elemento que perpassa todas as narrativas em tecnologias reprodutivas, tanto de diagnóstico pré-natal quanto de reprodução assistida, é a questão das escolhas que se apresentam como possíveis diante da identificação de uma condição já existente no feto ou no embrião. Para Rapp (2000), tais tecnologias fazem sentido quando o acesso ao aborto é garantido legalmente.

É dito que a deteç̧ão pré-natal de 'problemas' como a SD permite a preparação e a escolha de estratégias de tratamento a serem executadas durante a gestação ou imediatamente após o parto. Contudo, a decisão sobre manter ou interromper a gestação não faz parte do leque de escolhas possíveis, não apenas por crenças ou valores individuais ou de grupos sociais, mas fortemente justificada por seu aspecto (i)legal.

A relevância desse aspecto encobre outros matizes importantes da discussão, como a incômoda perspectiva de se fazer uma escolha que soe como eugênica, ao se determinar quais formas de ser humano poderiam ser evitadas. ${ }^{26}$ Percebe-se, nos interstícios do escopo das tecnologias reprodutivas, duas fortes tendências que se conectam de forma conflitante: os direitos reprodutivos, cuja regulamentação no Brasil encontra-se ainda sob forte influência de caráter religioso, e os direitos das pessoas com deficiências, contrapondo temas como aborto e inclusão.

O que antes era entendido como fado na biopolítica contemporânea torna-se oportunidade, esperança, alento, com alívio do peso do 
determinismo, embora em muitos discursos ainda soe como tal. A possibilidade oferecida pelas intervenções no nível molecular de escolher entre ter ou não um filho afetado por uma condição específica suscita intenso debate na tentativa de definir um possível recrudescimento ou novas releituras de uma postura eugênica.

O termo eugenia foi criado por Francis Galton em 1883, como uma estratégia biopolítica de melhoramento da 'raça humana'. De cunho darwiniano, o foco era colocado não no indivíduo, mas na população territorializada numa nação e submetida a uma governança interna (Foucault, 2003d). Os indivíduos que compunham essa população seriam avaliados em termos da sua 'qualidade' evolutiva, manifesta por suas aptidões físicas e mentais: aqueles considerados como os melhores seriam encorajados a procriar livremente para a melhoria do corpo político, a chamada eugenia 'positiva', enquanto os considerados de nível inferior, ou menos aptos, devido a algum tipo de defeito ou doença, seriam limitados em suas opções reprodutivas, a eugenia 'negativa', como forma de evitar o peso econômico e social advindo de uma situação de degenerescência que levaria ao enfraquecimento da coletividade. No começo do século XX, uma nova onda higienista teve lugar ressaltando técnicas de cuidado individual à saúde física e moral, configurando outra estratégia estatal além daquela eugênica, cujo foco era a reprodução. A face eugênica assumida pelo regime nazista foi resultado da conjunção de numerosas outras tendências e debates sobre raça; entretanto, constitui, nos dias atuais, a referência máxima de eugenia, com seus fantasmas, a ser evitada. O termo eugenia ainda é considerado como uma espécie de rótulo com múltiplos usos, de grande valor simbólico, aplicado a situações de pesquisa em diversas áreas, seja para enfraquecer determinado enfoque considerado controverso, seja para estimular novos rumos não aventados por questões de preconceito (Ramsden, 2009).

A biopolítica molecular contemporânea é considerada por críticos como Giorgio Agamben (1998) como ainda tendo o seu foco intrínseco no controle e na eliminação de elementos estranhos a um corpo político, por meio de uma tanatopolítica, ou política de morte; entretanto, autores como 
Paul Rabinow e Nikolas Rose (2006) argumentam que o que a caracteriza não é passível de ser descrito como mera repetição ou variação de um passado. Após a Segunda Guerra Mundial, o interesse da genética voltouse para a busca da origem das doenças no âmbito da saúde individual, com o foco em elementos como os genes e suas funções no nível molecular. Ainda que, hoje, a vida esteja sob escrutínio em termos valorativos, o que está em questão não diz mais respeito a um corpo político territorializado, cuja qualidade deve ser maximizada para competir com outro, mas a indivíduos que são instados a assumir escolhas relativas à sua saúde pessoal ou familiar.

Ao mesmo tempo que o Estado manteve determinadas funções de legislar sobre a saúde (por exemplo, sobre padrões de qualidade de serviços básicos como água e esgoto, ou sobre comida), observou-se um movimento de redução da responsabilidade pela garantia da saúde individual, com emergência de serviços privados de saúde e com delegação aos próprios indivíduos da responsabilidade por se administrar (Miller \& Rose, 2008a). Assim, a biopolítica contemporânea exerce-se nos microespaços dos lares e comunidades em busca de qualidade de viver, o que inclui questionamentos e ações com respeito à prevenção ou término da vida, como na contracepção, diagnóstico pré-implantação, aborto ou eutanásia, que emergem em consonância com a pluralidade de molduras por meio das quais os indivíduos enxergam o mundo.

O corpo flexível, aberto à possibilidade de intervenção molecular a fim de ser melhorado em seus aspectos vitais, é contraposto a determinadas referências corporais consideradas mais desejáveis, numa sociedade em que o individualismo e a oportunidade de escolha apresentam-se como valores básicos, alinhados com os modos de subjetivação implícitos nos modelos liberais avançados ocidentais (Rabinow \& Rose, 2006). Todavia, parece inadequado considerar essa situação como um revigorar do pensamento eugênico. Os cenários são diferentes, e as interações que hoje se observam são mais intersticiais. O desejo de pais por evitar ou minorar o sofrimento de seus filhos com algum tipo de deficiência ou a dor da perda de um deles, que os fazem se engajar num movimento para financiar pes- 
quisas em busca de tratamentos ou cura, ou em prevenção ativa pela restrição de nascimentos, não parece se encaixar na ideia de melhoramento do corpo político de uma determinada nação por meio de ações governamentais. Antes, configura-se como um redelineamento de valores éticos e responsabilidades que permita melhor administrar a existência social e biológica, e é expressão daquilo que Carlos Novas (Novas \& Rose, 2000) sinalizou como sendo uma economia política de esperança, na qual se espera que a identificação de disfunções no nível genômico conduza à intervenção molecular e a uma vida melhor.

Muitas críticas também são feitas no sentido de que a biopolítica contemporânea, ao focar na 'vida em si', reduziria o indivíduo ao seu âmbito biológico, desconsiderando, ou mesmo eliminando, aspectos existenciais outros (Ortega, 2004; Castiel \& Álvarez-Dardet, 2007). Em tempos de uma saúde persecutória centrada na noção de risco, a responsabilização individual, reafirmada pelo discurso da promoção à saúde, impulsiona a busca desenfreada por uma saúde futura e por longevidade, por meio de vigilância e prevenção constantes na tentativa de tornar previsíveis as ameaças potenciais, mas que podem ter como consequência a limitação da vida humana aos aspectos somáticos (Castiel \& Álvarez-Dardet, 2007).

Entende-se que a modificação trazida pelo estilo de pensamento molecular, e que transcende um mero aprofundamento do olhar como o que ocorreu com o conhecimento anatomoclínico, promove uma reorganização na maneira de se compreender o ser humano, em seus corpos, identidades, pensamentos, vontades, desejos e comportamentos, em que o aspecto somático é relevante, mas não o único. As relações que o indivíduo estabelece consigo mesmo e com o mundo, a partir de novas formas de conhecimento de si, envolvem um intrincado tecido de relações e práticas definidoras de formas de governar indivíduos e grupos que não são redutíveis a uma visão biologizante ou genomizante. Essas novas relações são incorporadas, e novas verdades são produzidas.

É nesse sentido que a expressão de Ortega y Gasset (2007) é revisitada e adquire sentido como analogia, permitindo o delinear de novos percursos e a criação de novas imagens e elementos imaginativos mais adequados 
que possam traduzir o que hoje significa ser humano em suas mais variadas formas de viver.

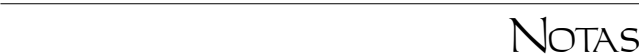

1 Interpretação dada por José Ortega y Gasset (2007) à vida humana individual e coletiva.

2 Em última instância, o autor refere-se à realidade espanhola com seus problemas e contradições.

3 Em reportagem no jornal O Globo, caderno Jornal da Família, em 27 out. 2002: a imagem de algo que se assemelha a um óvulo, num olhar microscópico, circundado por um meio aquoso que sugere uma expansão. A manchete diz: "Óvulo turbinado" (reafirmando a imagem); e o subtítulo complementa: "Novo tratamento médico que permite a gravidez tardia faz sucesso e causa polêmica entre os especialistas".

4 Por exemplo: "O doutor é animal: a zooterapia conquista credibilidade e ganha mais espaço no tratamento de uma série de distúrbios" (Veja, seção Saúde, em 30 nov. 2005).

5 Como na reportagem "Decifrado cromossomo 21 do homem: trabalho promete levar a tratamentos e testes para síndrome de Down e mal de Alzheimer" (O Globo, seção O Mundo/Ciência e Vida, em 9 maio 2000).

6 Como a metáfora do genoma humano como 'código' ou 'livro', por exemplo, em que as bases A, C, G e T são 'letras' e os cromossomos, 'fascículos' (O Globo, "Sequenciaram o genoma... E daí?", Primeiro Caderno, seção Opinião, em 31 jul. 2000).

7 Disponível em: <http://www.serdiferenteenormal.org.br>. Acesso em: 22 mar. 2009.

8 O Globo, "Outros olhos", Segundo Caderno, Coluna Gente Boa, 14 jun. 2007.

9 O Globo. "Lições de superação". Jornais de Bairro/Barra, 3 set. 2006.

10 Trechos extraídos de reportagem "Além dos limites", na Veja, seção Saúde, em 29 mar. 2000. Grifos meus.

11 O Globo, "Sequenciaram o genoma... E daí?", Primeiro Caderno, seção Opinião, em 31 jul. 2000 .

12 Os modelos animais são citados na Veja, "Estudo indica gene causador de Down", seção Ciência, em 6 jul. 2006; na reportagem "Síndrome de Down: origem em célulastronco, Notícias on-line, seção Ciência e Saúde, 5 set. 2008. Em O Globo, "DNA-lixo?, Primeiro Caderno, seção Opinião, em 22 maio 2002; "DNA de camundongo é 80\% igual ao humano", Primeiro Caderno, seção O Mundo/Ciência e Vida, em 5 dez. 2002. 
13 Veja, "O mapa do 21", seção Genética, em 17 maio 2000; O Globo, "Decifrando o cromossomo 21 do homem", Primeiro Caderno, seção O Mundo/Ciência e Vida, em 9 maio 2000.

14 O Globo, "Proteínas são o segredo da nova medicina", Primeiro Caderno, seção O Mundo/Ciência e Vida, em 23 jul. 2000. O estudo da estrutura e das funções das proteínas é feito por um campo da bioquímica, a proteômica (Nussbaum, McInnes \& Willard, 2002).

15 Veja, "A descoberta da molécula 'Down"', seção Ciência, em 6 dez. 2005. Disponível em: $<$ http://veja.abril.com.br/noticia/arquivo/descoberta-molecula-down>. Acesso em: 28 nov. 2006.

16 Veja, "Estudo indica gene causador de Down", seção Ciência, em 6 jul. 2006. Disponível em: <http://veja.abril.com.br/noticia/arquivo/estudo-indica-gene-causador-down>. Acesso em: 28 nov. 2006.

17 Um exemplo desse tipo de tecnologia encontra-se na reportagem sobre técnica de rejuvenescimento de óvulos, por meio da inclusão de uma pequena porção de citoplasma de uma doadora mais jovem. Uma forma de compensação para perdas decorrentes da idade - erros no processo de divisão celular - torna-se possível pela plasticidade e possibilidade de reprogramar as células e promover desenvolvimento adequado $(O$ Globo, "Óvulo turbinado", seção Jornal da Família, em 27 out. 2002).

18 Veja edição especial "O relógio biológico deles", A Melhor Idade, seção Família, em 31 ago. 2005 .

19 Veja, "Check-up", seção Especial, em 28 jun. 2000.

20 Friedrich Nietzsche (1996) reconta o mito de Pandora, salientando que a esperança ficou dentro da caixa enviada por Zeus aos homens para garantir que estes seriam atormentados por toda a vida. Assim, ele considera a esperança como o "pior dos males", por prolongar o sofrimento dos homens (Nietzsche, 1996: 45).

21 Veja, "Teste Genético para 140 milhões", seção Medicina, em 10 dez. 2008.

22 Contudo, nada é dito nas reportagens acerca das dúvidas que pairam em relação à melhor combinação de métodos a ser feita para rastreamento e diagnóstico da SD, como quais marcadores bioquímicos devem ser testados e como combiná-los, por exemplo (Kerr, 2004).

23 Trecho extraído do jornal O Globo, "Classe média gasta 10 mil com gravidez", seção Jornal da Família, em 28 mar. 2004.

24 Os dois trechos são extraídos de reportagem da Veja, "Retratos do bebê antes do parto", seção Guia Filho, em 18 set. 2002.

25 Citações retiradas de reportagem no jornal O Globo sobre técnica de rejuvenescimento de óvulos, já citada ("Óvulo turbinado", seção Jornal da Família, em 27 out. 2002). 
A técnica foi alvo de numerosas críticas e controvérsias pela escassez de informação sobre as consequências de transferência de DNA mitocondrial.

26 Por exemplo, a reportagem da Veja, "Exame pré-natal poderá acusar autismo", seção Ciência e Saúde, em 12 jan. 2009, sobre técnica desenvolvida na Inglaterra para detecção de casos de autismo, o que permitiria a escolha por parte dos pais de levar adiante a gestação, traz o questionamento do próprio pesquisador sobre a validade desse tipo de identificação pré-natal ao destacar os valores associados a essa condição, como talento e genialidade, em contraste com os associados à SD. Ou ainda na Veja, "A terrível escolha", seção Ética, em 16 mar. 2005, sobre eutanásia neonatal na Holanda em casos de doenças graves (uma delas, SD). 